\title{
Effect of Mapping Concept and TAPPS on Students Critical Thinking of Chemical Bonding
}

\author{
$1^{\text {st }}$ D.M Pratiwi \\ Department of Chemistry Education, \\ Universitas Pendidikan Indoneia, \\ Bandung, Indonesia, 40154 \\ dillamulyapratiwi@gmail.com
}

\author{
$2^{\text {nd }}$ F M Titin Supriyanti \\ Department of Chemistry Education, \\ Universitas Pendidikan Indoneia, \\ Bandung, Indonesia, 40154
}

\author{
$3^{\text {rd }}$ Hernani \\ Department of Chemistry Education, \\ Universitas Pendidikan Indoneia, \\ Bandung, Indonesia, 40154
}

\begin{abstract}
Chemistry is a complex subject that explores a number of abstract topics and concepts. Many of these fundamental conceptual interconnections present in chemistry. The use of concept mapping and thinking aloud pair problem solving (TAPPS) to increase critical thinking of senior high school student, focused on chemical bonding concept. Herein, we spotlight the concept of ion and covalent. In this research used a quasi experiment, pre-test and post-test design. In essence, the study found that the advantages and disadvantages both of them. The mapping concept was able to increase a critical thinking of student and TAPPS was able to increase problem solving skill of student.
\end{abstract}

Keywords - mapping concept, tapps, critical thinking, chemical bonding.

\section{INTRODUCTION}

Chemistry is a complex subject that explores a number of abstract topics and concepts. This understanding of chemistry requires students to understand some interrelatedness of concepts and ideas. That is, they develop a coherent structure of knowledge. In some studies it defines a "knowledge structure" as a scheme in which students organize and relate various concepts to understanding a particular topic [1].

In the learning process, children are less encouraged to develop thinking skills because the process of learning in the classroom is directed to the child's ability to memorize information. The child's brain is forced to remember and hoard information without being required to hone and develop higher thinking skills of critical thinking [2]. As a result of rote students can not effectively connect new information with prior knowledge. Another consequence of rote is that new material is simply memorized, easily forgotten and not transferred [3, 4].
Critical thinking is considered an indispensable skill to adapt to the development of science and technology in life [5]. In fact, everyone can think, but not necessarily the result of the thinking can be entirely trustworthy because many of the results of thinking are sometimes distorted, mistaken, only partial, or only limited preconceived [6]. The skill dimension referred to from permendikbud No. 20 of 2016, students are expected to have one of critical thinking skills [7].

Concept mapping is one of the instructional tools to promote whether Ausubel has been described as meaningful learning; meaningful learning refers to new ideas or concepts with previously acquired knowledge Concept mapping is one of the instructional tools to promote whether Ausubel has been described as meaningful learning; meaningful learning refers to new ideas or concepts with previously acquired knowledge.

Another study, conducted by Jeon Kyungmoon [8], states the use of TAPPS as a means to engage students in complex cognitive processes to solve problems. Verbal interaction between the breaker and the listener can help students become more aware of their own thinking and from other students' thinking Chemical problem solving in the real world is usually a collaborative process, and therefore it is important for all students to develop their respective thinking skills. Chemical instructors are encouraged to promote oral interaction between students as a tool to help all students improve achievement in chemistry.

Chemical bonding is an important concept in chemistry, some misconceptions found in high school students about this concept, where chemical bonding is a continuing concept of subsequent material, including organic chemistry at the university level. Students are still confused in distinguishing ionic bonds, covalent bonds, polar and non polar covalent bonds. [9].

Based on the above background, it has been conducted research that aims to determine the effect of 
concept mapping and TAPPS to improve critical thinking of high school students in chemical bonding material.

\section{METHOD}

The research method used in this research is quasi-experiment research. This study used a research subject that was unrandomly, conducted in one of Senior High School in Indramayu with $\mathrm{N}=30$ students in each experiment. Experiment $\mathrm{I}$ in this study used mapping concept and the experiment II using model Thinking Aloud Pair Problem Solving (TAPPS). [10]. The research design used was Prettest-Posttest, Nonequivalent Control Group Design. In this design, both groups were given a pretest to see the similarities of both research groups, where the pretest score had a strong relationship with the dependent variable of this study).

Table 1. Research Design

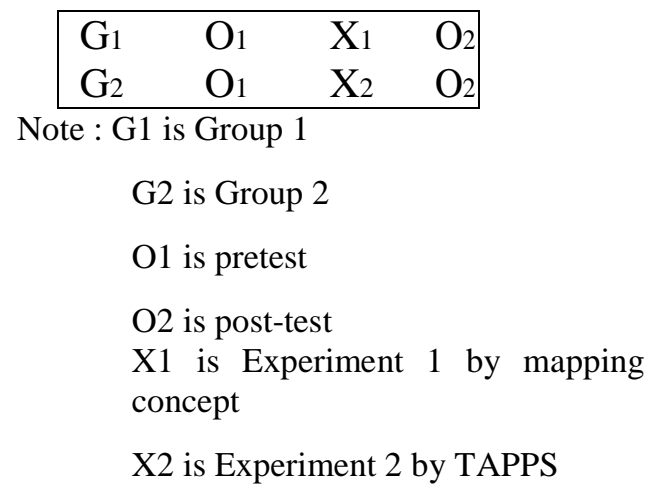

$\mathrm{X} 2$ is Experiment 2 by TAPPS

\section{DISCUSSION}

Concept mapping is one of the instructional tools to promote whether Ausubel has been described as meaningful learning; meaningful learning refers to new ideas or concepts with previously acquired knowledge [11].

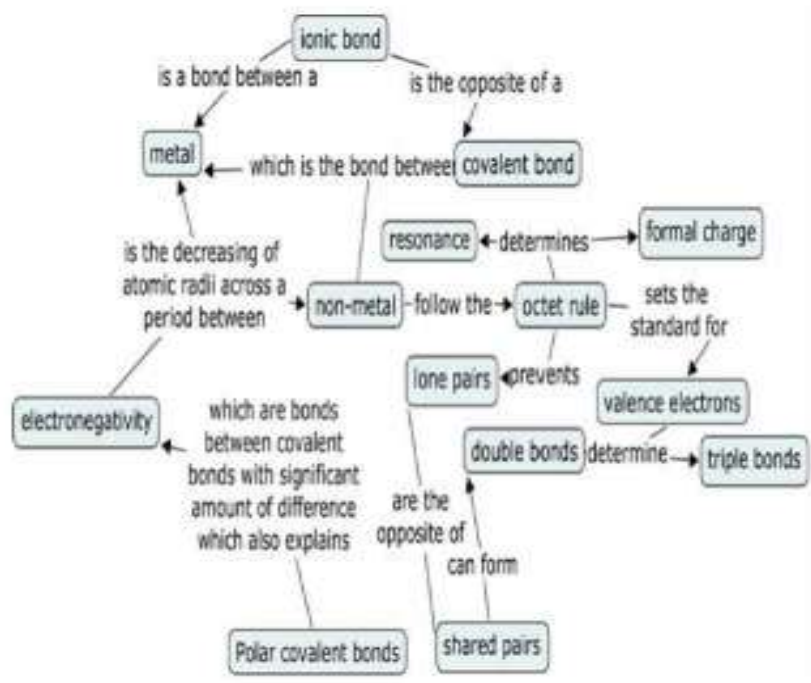

Figure 1 . Example of Mapping Concept

\section{Thinking Aloud Pair Problem Solving}

The learning model of Thinking Aloud Pair Problem Solving (TAPPS) is one of the development of cooperative learning model, where students learn in groups (cooperative). Students are trained and familiarized to exchange knowledge, communicative discussions, and share duties and responsibilities answered within specified groups [12]. 


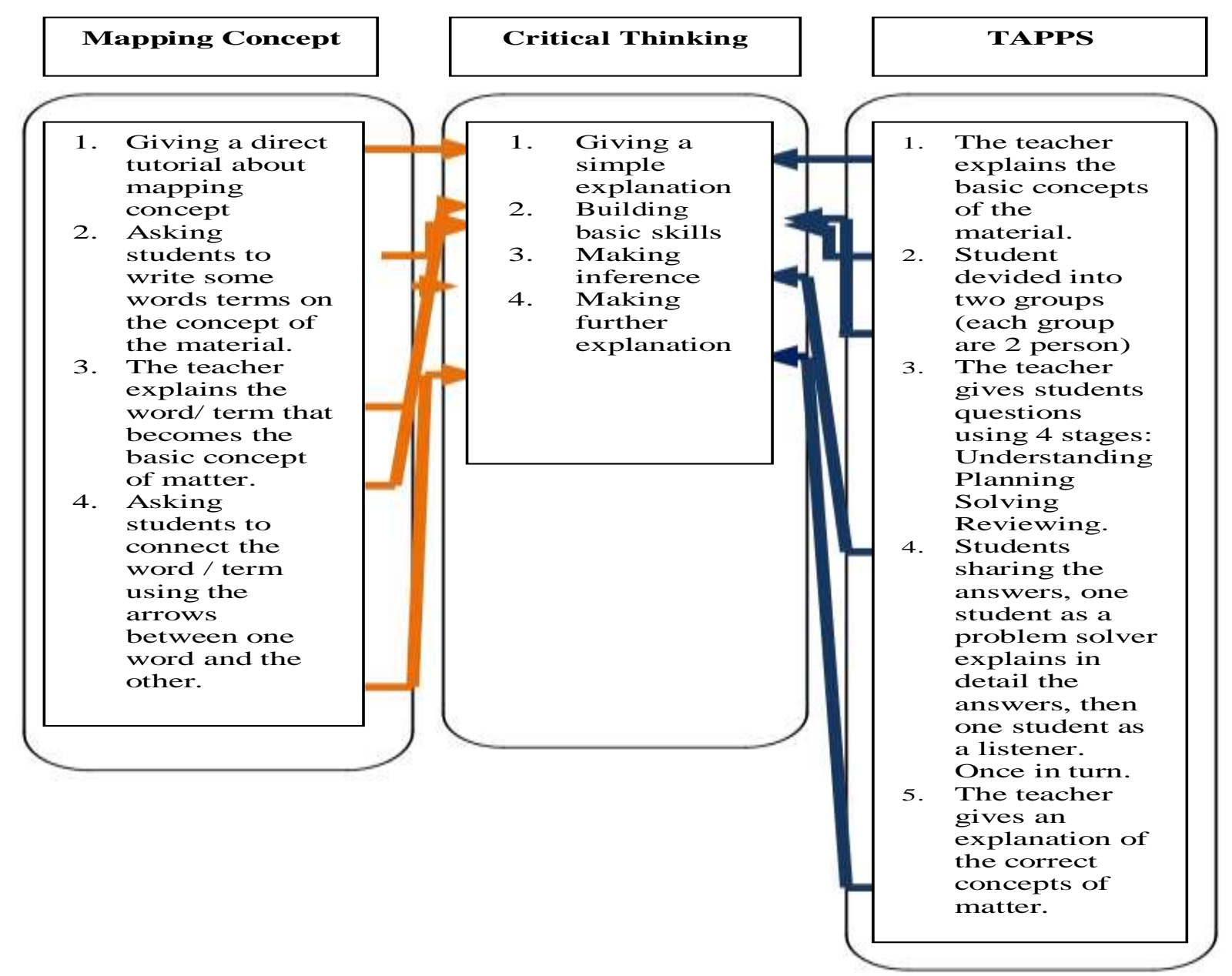

Both of experiment using "worksheet" for verifying the result which the experiment increasing student critical thinking.

The result in this study students sum concept map scores were an indication of how well they understood bonding concepts overall. The concept maps gave us insight into their overall knowledge structures and allowed us to pinpoint specific gaps in students' knowledge.

Examining students' prior knowledge in terms of their overall knowledge structures will help chemical educators design more meaningful curriculum materials. Mapping concept can be used as a preassessment and formative assessment tool to analyze students' knowledge structures regarding a group of related concepts. Chemical educators can determine which concepts and connections need to be more explicitly taught and can address common misconceptions and knowledge gaps.

For TAPPS strongly that our current methods of teaching chemistry are perhaps, not teaching chemistry, but teaching how to get answers to selected the problems. This study supports efforts being made to involve conceptual-teaching pedagogics into our classrooms. We have identified a reliance of our students chemical bonding to solve problems, even problems specifically intended for conceptual solution. We have reaffirmed the notion that current method does not necessarily lead to conceptual learning.

\section{CONCLUSION}

Mapping concept can be used as a pre-assessment and formative assessment tool to analyze students' knowledge structures regarding a group of related concepts. Chemical educators can determine which concepts and connections need to be more explicitly taught and can address common misconceptions and knowledge gaps.

For TAPPS strongly that our current methods of teaching chemistry are perhaps, not teaching chemistry, but teaching how to get answers to selected the problems. This study supports efforts being made to involve conceptual-teaching pedagogics into our classrooms. We have identified a reliance of our students chemical bonding to solve problems, even problems specifically intended for conceptual solution. We have reaffirmed the notion that current method does not necessarily lead to conceptual learning.

\section{ACKNOWLEDGMENT}

The authors would like to thank for all those who have assisted in this research. 


\section{REFERENCES}

[1] Novak, J. D. (2010). Learning, Creating, and Using Knowledge: Concept Maps as Facilitative Tools in Schools and Corporations: Routledge.

[2] Sanjaya, W. 2006.Strategi Pembelajaran. Jakarta: Kencana Prenada Media Group R. C. Mikkelson (private communication).

[3] Novak, J.D \& Gowin, D.B. 1984. Learning How to Learn.London : Cambridge University Press.

[4] Halpern, D. F. (1998). Teaching Critical Thinking for Transfer Across Domains Dispositions, Skills, Structure Training, and Metacognitive Monitoring. American Psychologist. 53(10), 449-455.

[5] Paul, R. \& Elder, L. (2008). The Miniature Guide to Critical Thinking Concept and Tools. [Online]. Diakses dari http://www.criticalthinking.org
[6] Peraturan Menteri Pendidikan dan Kebudayaan.(2013). Implementasi Kurikulum. Jakarta: Depdikbud.

[7] Noh, T.; Jeon, K. J. Kor. Assoc. Res. Sci. Educ. (in Korean) 2005,17, 75-83.

[8] Burrows, Nikita L\& R.Mooring. (2015). Using concept mapping to uncover students knowledge structures of chemical bonding concepts.Journal of Royal Society of Chemistry, 16(2), p. 53-66.

[9] Wiersma, W., \& Jurs, S.G. (2009).Research Methods in Education.United State of America: Pearson.

[10] Felder, Richard M, (1994). Cooperative Learning in Technical Corse.

[11] Fisher, A., Scriven, M. (1997) “Critical Thinking : Its Definition And Assessment.”. Edgepress And Center For Research In Critical Thinking : University Of East Anglia. 